Rev. Latinoam. Psicopat. Fund., São Paulo, v. 11, n. 1, p. 166-169, março 2008

Yes, nós temos Pasteur: Manguinhos, Oswaldo Cruz e a História da Ciência no Brasil

Henrique Cukierman

Rio de Janeiro: Relume-Dumará/Faperj, 2007, 440 págs.

\title{
Forjar a nação moderna e o homem brasileiro: ação e reflexividade da ciência
}

\author{
Ademir Pacelli Ferreira
}

"Bem longe, no perau profundo, vive o brasileiro nos confins do mundo. Transido de culpa, pecado, desespero e aflição, sonha outros destinos e arde no desejo de ocupar o centro. Quer largar as abas e as margens, quer incluir-se e ser incluído. Quer ser como aqueles que servem de exemplo e, por isso mesmo, tem de construir símbolos de que aqui não é o fim do mundo...". Assim começa seu livro, Yes, nós temos Pasteur, Henrique Cukierman, demonstrando de forma cabal a entrada do Estado iluminado pelo espírito científico para contrapor a idéia de um naturalismo nativo, que emperrava o desenvolvimento de nosso país como nação moderna. A ciência, atrelada aos aparelhos instituidores e mantenedores das leis, teve a função de redimir a nação de seu atraso e de fundar o homem da metrópole.

A investigação desta história da constituição da saúde pública nacional a partir de Manguinhos e da liderança de Oswaldo Cruz, 
que é também, entendemos, a história da consolidação do Estado Brasileiro, articula a limpeza da cidade, a higienização das casas e a obrigatoriedade das vacinas com o ideal de um país espelhado na Europa franco-saxônica, sustentado no discurso e na ideologia do saneamento do espaço e das mentes na constituição do novo homem brasileiro. Se, por um lado, aparece um discurso nacionalista, ele decorre de um sonho de constituir aqui uma réplica européia. No otimismo desse vislumbre grandioso, estava o desejo de contrapor a imagem de um país agrário e arraigado ao conservadorismo com o progresso da ciência e da tecnologia.

Cukierman afirma tratar-se de uma história que elabora o mito de fundação da tecnociência brasileira, restaura as chances de inserção do país no concerto das nações civilizadas, define uma dinastia nativa de cientistas campeões, exibe um magote de sucessos e vitórias e institucionaliza um templo mourisco do saber para as futuras gerações. Nas narrativas desta epopéia, depreende-se o estilo da batalha bélica, em que combatia estoicamente de variola a valores, ratos a raízes coloniais, de mosquitos a mentalidades burocráticas.

Como ocorreu com a psiquiatria de Juliano Moreira, que foi buscar na Alemanha de Kraepelin o modelo para a nova psiquiatria brasileira, esta que, até então, seguia a tradição francesa, a história de Manguinhos cotejou estes dois centros: Oswaldo, filiado à Paris de Pasteur e seu parceiro de saga, Rocha Lima, à Munique e Berlim, onde a ciência de Manguinhos foi reverenciada com o primeiro prêmio em higiene em 1907. Estabeleceu-se aí o marco da chamada ciência autóctone do Brasil. Sim, não somos macacos, temos nossa ciência, produzimos também os meios técnicos e criamos produtos tecnocientíficos.

Nessa batalha de heróis, os homens de ciência terão um papel que se inverte: de colonizados pelos centros europeus, serão aqui colonizadores na ação de modelação do brasileiro moderno. Grande contradição das ações de uma tecnociência moderna em um país nada moderno, na qual o escravagismo grassava nos espíritos de uma elite vestida de europeu.

Colonização esta que evocava o espírito das luzes do norte europeu contra o arcaismo lusitano e o relaxamento afronativo. Para entrar na era das máquinas, da tecnologia e da ciência, fazia-se urgente combater a lassidão luso-nativaafricana, em que grassava o império dos mosquitos e seus súditos culicídeos. $\mathrm{O}$ sol temperado do norte europeu, sem as malignidades, o bem-logrado sol dos países saneados, deveria aqui banhar os trópicos e vencer a lassidão, saneando os espaços e as mentes da infecciosa atração viscosa do sol escaldante.

O Estado, em sua constituição na modernidade, adotou a racionalidade científica, revestida da idéia de neutralidade e universalidade como discurso de sustentação de suas metas de ordenação e de domínio hegemônico dos espaços, 
das mentes e do mundo. A reconstituição da saga de Oswaldo Cruz e de Manguinhos e sua relação com a consolidação e a intervenção do Estado no dia a dia dos habitantes da cidade do Rio de Janeiro, contada de forma rigorosa, fluida, bem-humorada, além de muito original, por Henrique Cukierman, retrata essa parceria tão estreita entre intervenção do Estado e ação da tecnociência no campo da saúde pública. Ao caminhar com as referências de Latour e Buarque de Holanda, o autor explorou em profundidade o terreno socio-histórico amplo e dissecou as particularidades brasileiras, o que dá ao livro um valor especial.

As exigências de intervenção sanitária convocavam os médicos, que tradicionalmente exerciam a arte de aliviar os sofrimentos dos indivíduos enfermos, do desafio de dirigirem uma missão grandiosa: sanearem a cidade capital para ser o espelho de uma nação que se pretendia civilizada e moderna como a Europa.

Trata-se de uma obra que resgata os fatos e artefatos científicos e os analisa como construções sociotécnicas. Ao seguir a esteira dos chamados Estudos Ciência-Tecnologia-Sociedade, demonstra-se que estas intervenções sociocientíficas produziram importantes efeitos de reflexividade na transformação da realidade moral e material do Brasil. Nesse sentido, em sua resenha desta obra, Laymert dos Santos, na Folha de São Paulo de 7/10/2007, indica o capítulo que analisa a erradicação da febre amarela na capital da República como paradigmático para a demonstração de tal projeto sanitário, que atesta a vontade científica, técnica, política, administrativa e cultural de refundar o país ou de reinventá-lo.

Sabemos que forças econômicas tocavam a máquina saneadora desse projeto, como a necessidade de sanar os portos e garantir o escoamento dos produtos agrícolas, além de melhorar a imagem do país na disputa de imigrantes europeus. Mas o ímpeto do controle sanitário trazia no seu bojo a vigilância e o controle social das populações, o que acarretou na Revolta da Vacina, a qual, para os dirigentes sanitários, deveria ser sufocada, já que representava a manifestação do atraso e da ignorância.

Cukierman buscou produzir diferenças ao recontar esses contos de nossa história, favorecendo a linha da investigação renovada, na qual compreender a fabricação de um fato científico ou de um artefato tecnológico implica desvendar o duplo movimento pelo qual são construídos e encontram seu espaço de aceitação e circulação, cabendo então analisar as redes que os engendram, sem as quais seriam esvaziados de todo conteúdo e todo futuro.

Para Ivan Marques, em seu posfácio do livro, Cukierman desfaz as separações epistemológicas entre, de um lado, o subjetivo, o social, o cultural e o político, entre o dentro e o fora da ciência para enxergar, apontar e descrever 
a complexidade e a heterogeneidade de um laboratório que constrói simultaneamente a natureza e a sociedade.

Os leitores serão testemunhos de que o autor foi muito feliz nesta reconstrução histórica. Neste espelhamento de nosso passado, somos afetados e convocados a refletir sobre o lugar que ocupamos neste sonho de produzir ciência e tecnologia no Brasil e sobre o desejo de participar da construção de um país mais justo e igualitário, do qual possamos ter mais orgulho. Portanto, um livro que vale a pena ser lido por todos aqueles que se preocupam com a construção e a desconstrução dos mitos nacionais.

\section{Ademir Pacelli Ferreira}

Professor Adjunto do Instituto de Psicologia da Universidade Estadual do Rio de Janeiro (Rio de Janeiro, RJ, Brasil); membro da Associação Universitária de Pesquisa em Psicopatologia Fundamental (São Paulo, SP, Brasil); autor do livro O migrante na rede do outro (Tê Corá, 1999) e de vários artigos sobre saúde mental, clínica e psicopatologia.

Rua Uruguai, $449 \mathrm{~b} / 402$

20510-065 Rio de Janeiro, RJ, Brasil

Fone: (21) 2238-5217 / 2568-5749 - Fax: (21) 2587-8752

e-mail: ademirpacelli@uol.com.br 